Received: November 4, 2017

Revision received: April 21, 2018

Research Article

\title{
Research on the Education of Industry-Education Integration for Geological Majors*
}

\author{
Jiaguo Ren ${ }^{1}$ \\ Shandong University of \\ Science and Technology \\ Ke Gong ${ }^{4}$ \\ Shandong University of \\ Science and Technology
}

\author{
Qianqian $\mathrm{Wu}^{2}$ \\ Shandong University of \\ Science and Technology \\ Dongsheng Wang ${ }^{5}$ \\ Ocean University of China
}

\author{
Zuozhen $\mathrm{Han}^{3}$ \\ Shandong University of \\ Science and Technology
}

\begin{abstract}
The talent education model of "industry-education integration" has matured in some European countries. Foreign countries promote the integration of production and education in the national macro level and implement school-enterprise cooperation at the micro level. We identified the aims and models of the geological talents training and identified the direction of geology education reform through analysis and discussion. We can take the combination of industry and education at each stage of talent training by the means of making new training programs, reforming teaching contents and methods. The employment of geological undergraduates can be improved effectively by taking a multi-level talent training mode of geology majors with deep integration of production and education.
\end{abstract}

\section{Keywords}

Geological • Industry-Education Integration • Double-Teacher

\footnotetext{
*This work is funded by Scientific Research Foundation of Shandong University of Science and Technology for Recruited Talents (No.2016RCJJ009), Stars plan Project of Shandong University of Science and Technology (QX2018Z02),Shandong Provincial Natural Science Foundation (ZR2017MD009) and National Natural Science Foundation of China (No. 41202165, No. 41102149).

${ }^{1}$ College of Earth Science and Engineering, Shandong University of Science and Technology, Qingdao 266590, China. Email: renjiaguo2008@126.com

2 Correspondence to: Qianqian Wu, College of Earth Science and Engineering, Shandong University of Science and Technology, Qingdao 266590, China. Email: wqq912@126.com

${ }^{3}$ College of Earth Science and Engineering, Shandong University of Science and Technology, Qingdao 266590, China. Email: hanzz@163.com

${ }^{4}$ College of Earth Science and Engineering, Shandong University of Science and Technology, Qingdao 266590, China. Email: 970306268@qq.com

${ }^{5}$ Ocean University of China, Qingdao 266100, China. Email: wds@ ouc-edu.com
}

Citation: Ren, J. G., Wu, Q. Q., Han Z. Z., Gong, K., Wang, D. S. (2018). Research on the Education of Industry-Education Integration for Geological Majors. Educational Sciences: Theory \& Practice, 18(5), 1315-1322. http://dx.doi.org/10.12738/estp.2018.5.030 
The talent training model of "Industry-Education Integration" first appeared in some European countries. The typical one was the model which was called "business-oriented, school-assisted". The integration between industry and education began with the Philip J. Foster's opinion which is called "Industry-University Cooperation" educational form. Foster's viewpoint shows "the consensus of a developing model of professional education by governments, industry associations, enterprises, institutions, experts and scholars in professional education developed countries". It has established a relatively perfect legal protection system, implementation and operation mechanism and practical mode in the industry-university cooperation and the school-enterprise cooperation in some countries like Germany, Australia, Japan, the United States, and England. Such as "dual system", "cooperative education" and" industry-university cooperation "And "sandwiches", etc.

Foreign countries promote the integration of production and education in the national macro level and implement school-enterprise cooperation at the micro level. The development of vocational education must involve multiple parties, including government departments, industry associations, business organizations, educational institutions, and some non-profit organizations. We can't achieve the goal of industry-education integration, school-enterprise cooperation if there is no multi-level cooperation between industry and education, industry associations and educational institutions, enterprises and schools (Akomaning, Voogt, \& Pieters, 2011).

In China, the exploration of industry-education integration can be traced back to modern industrial education. Later, it was a "work-study" the early days of the nation, and now it is a " work-study combined and the school-enterprise cooperation", And formed a variety of effective modes, such as "professional teaching+campus demonstration base, key majors+school-run enterprise, on-campus learning+fixed-point enterprise internship, school+company+user, school-enterprise combination, joint education, direct integration of teaching and production". Industry-education integration has become an important guideline for the development of vocational education in China (Alves et al., 2015).

The geological profession is a typical subject with strong practicality and applicability, the training talents must have great practical ability, innovative and hardworking spirit. We must carry out intensive Industryeducation integration to cultivate high-quality innovative talents in order to achieve this goal.

\section{Current education of geological talent in our school}

The Geology is one of the earliest academic departments in the history of Shandong University of Science and Technology. Our geological majors include three undergraduate majors: resource exploration engineering, geological engineering, exploration technology and engineering. The resource exploration engineering major is mainly to train senior professionals in the design, construction, management and scientific research of mineral resources exploration engineering. The geological engineering major mainly trains senior engineering and technical personnel engaged in engineering geological survey, geological hazard control and geological environment protection. Exploration technology and engineering majors mainly cultivate applied talents who use geophysical exploration technology and geochemical exploration technology to solve practical geological problems in exploration and mineral resources exploration. 
This major relies on the first-level disciplines of "Geological Resources and Geological Engineering", one doctorate station, stations for post-doctoral research, Shandong Provincial Key Laboratory, Engineering Technology Research Center and other academic platforms as well as outstanding scientific research innovations in Shandong Province Team, geological majors have solid teacher qualifications, strong research foundation and academic advantages.

Since the establishment of the geological major in 1957, we have cultivated about 10,000 geology talents for the society. We have developed annually 380 geological graduates in the past 10 years. It has made a positive contribution for the social development, especially to the development of the geological and mineral industry in Shandong Province. However, there exist some noticeable problems:

First, the funding of Practical teaching is tight. With the development of the times, the cost of talent education is increasing year by year, especially the cost of practical teaching increase with the increase in prices. For the geological majors with practicality, more field internships, and far-reaching internships, the internship funds are incurred tension, the effect of practical teaching is greatly restricted. Some kind of the geological majors is strongly practical. They have long journey field trips to lead to the tension of the internship funds, the effect of practical teaching is greatly restricted.

Second, the traditional mode of educating people with colleges and universities as the sole subject has many drawbacks. Such as poor practical ability, lack of innovation ability, disconnection from social needs, lack of social practice ability.

Therefore, it is crucial to explore the deep integration of talent training mode and establish long-term effective cooperation mechanism between schools and enterprises for the implementation and strengthening of Practical teaching, and it is an effective way to alleviate the shortage of internship funds.

\section{Construction of geological Industry-education integration education}

\section{Construction of talent training mode}

The geological specialty is mainly to cultivate applied talents, and the engineering practice is strong. In order to achieve better teaching and internship results, undergraduate students need to master the operation of large-scale equipment such as seismic surveying instruments, electric law instruments, geological radars, drilling rigs, logging tools, and data acquisition, processing analysis, interpretation techniques and methods. And it is also necessary to carry out teaching internships in conjunction with large-scale engineering projects. Colleges usually lack the advanced large-scale equipment commonly used by these construction units, they rarely undertake large-scale engineering projects for college students. Only by virtue of the resource advantages of enterprises and institutions, colleges and universities can achieve the training goal through the integration of production and education. However, the enterprises' engineering projects often conflict with the teaching hours in colleges. Adopting what kind of talent training mode can we realize the integration of deep Industry-education integration, and reach mutual benefit and reciprocity for a win-win result between enterprises and universities? 
It is necessary for universities and cooperative enterprises to carry out in-depth discussions and practical exploration.

Through extensive domestic and international research and research, drawing on successful experiences and practical cases, we will jointly analyze and research with cooperative enterprises and institutions, establish a platform for cooperation between industry, universities and research institutes, and jointly explore talent training models suitable for deep Industry-education integration in geology. Different majors, different courses, and different cooperative units explore the establishment of different and traditional talent training models with colleges as the sole subject.

\section{Formulating talent training programs}

With the continuous improvement in recent years, the geological professional training program of our school is currently compiled according to the four-school year combined with the credit system. The course types include general education, professional core courses, professional development courses, practice links, and innovation. Entrepreneurship education, etc., the proportion of credits in practice links has gradually increased, and innovation and entrepreneurship education has received increasing attention. And how to scientifically allocate the proportion between different types of courses, especially in combination with the requirements of deep Industry-education integration to develop a new talent training program.

We should conduct extensive investigation and research, fully integrate the theoretical system, structural framework, internal linkages and successful cases of Industry-education integration, and learn from the experience of other colleges and universities in geology and other science and engineering majors. We will fully utilize and utilize the talents and resource advantages of our undergraduate joint training units, and develop a new talent training program suitable for deep Industry-education integration.

\section{Improve the ability of innovation and practice}

Due to the limitations of the internship place, funds, and large-scale engineering equipment, it is difficult to ensure the time and quality of some field and engineering geology teaching internships. This leads to the actual effect of the practice link or the achievement of the training objectives to be strengthened. How to solve this problem that has long plagued us needs to be based on the goal of Practical teaching, teaching, production, scientific research, production, study, and research, and need innovative ideas to solve this problem.

Focusing on the content of professional core courses, deepening the reform and construction of Practical teaching, optimizing the curriculum teaching system, and improving students' applied innovation ability. In combination with the training plan, it is necessary to establish a number of internship bases to explore how to combine the engineering projects and scientific research projects of the enterprises and institutions with the teaching internships, production internships and graduate internships. How to encourage the use of college students by exploiting the flexibility of innovation and entrepreneurship education credits Extracurricular time to the enterprise and institutions to carry out professional internships, how to further combine the engineering 
projects and research projects undertaken by teachers with teaching internships, production internships and graduate internships.

\section{Play the role of new technology}

With the advancement of technology, such as the development of new technologies such as drones, virtual simulation, big data, cloud computing, etc., how to play the leading role of new technology on the basis of traditional education mode, how to bring the latest science and technology, such as the drones, virtual simulations, big data, and cloud computing into the formulation of geological talent training programs and teaching implementation plans is an issue that contemporary geological educators need to consider. Rationally integrate the above new technologies into the geological talents training process, promote the rational setting of the geological professional curriculum system, and make the geological professional construction and development keep up with the progress of the times. The advanced research in this aspect is of positive significance for cultivating innovative geoscience talents.

\section{Construction of the "double-teacher" team}

The implementation effect of Industry-education integration is crucial to the top-level design and the participation of teachers and students. The strength and input of the" double-teacher" team are crucial. Increasing the introduction and training of double teachers is one of the key points for the development of applied talents in colleges and universities. From enterprise appointed "the double teachers", the school's own original "the double teachers" how to cultivate and improve, the need for research and discussion (Sanchez, 2013).

Through a variety of ways, strengthening the construction of "double-teacher" team with both teaching and research ability and production practice ability is a powerful guarantee for Industry-education integration.

\section{College-enterprise cooperation}

Industry-education integration, school-enterprise cooperation is important breakthrough in the cultivation of applied talents. Through the establishment of a school-enterprise cooperation model for regional industries, deep Industry-education integration, optimization of various resources, formation of a talent training mechanism for collaborative education; through extensive research and negotiation, signing cooperation systems with enterprises and the mining industry, formulating systemized and standardized documents, clearly implementing management measures, and establishing effective reward mechanism restraint mechanisms (Lepori \& Kyvik, 2010).

There are many modes of cooperative education. In the geological specialty of our school, according to the nature of the profession, the nature of the cooperation unit and the different stages of engineering and research projects at different times, the cooperation forms of different modes are discussed and cooperative practice is carried out. Strive to achieve the purpose of improving the quality of personnel training through deep Industryeducation integration, and cultivate more qualified and outstanding talents for regional and industry development. In the practice and exploration, according to the actual situation and the problems found, timely 
summary, timely adjustment, and strive to form a set of geological professional training model innovation research results.

\section{Training mode and teaching reform}

Aiming at the problems existing in Industry-education integration in geology, we will construct a reasonable training mode and reform the teaching content.

\section{Training mode}

Constructing a scientific and rational training mode is an important guarantee for achieving the goal of Industry-education integration. Industry-education integration in geological majors must be "unified planning" or "overall designing" for undergraduate education and postgraduate education, and adhere to the guiding ideology of "multifaceted, solid fundamentals, high abilities and qualities". In view of the main weak links existing in China's geological education, we should focus on strengthening the cultivation of students' innovation awareness, innovative thinking and innovative ability, and must be consistently implemented in the education of this, master, and blog (Farias \& Sevilla, 2015).

Undergraduate training mode. Based on the above ideas, a three-stage undergraduate training model of " $1+2+1$ " is proposed (Fig. 1 ).

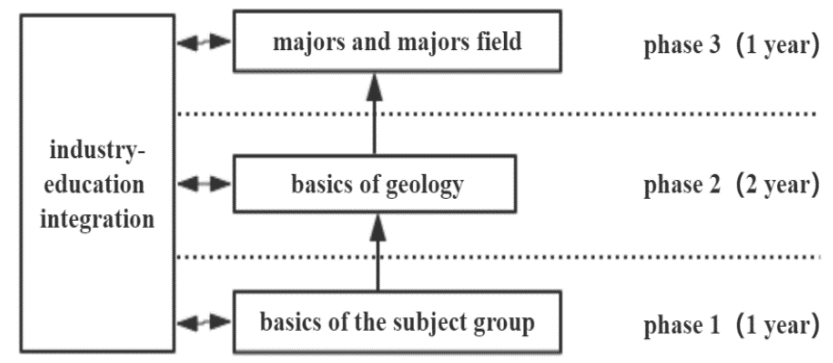

Figure 1. Geological undergraduate talent training mode.

The core of the model is "strengthening the foundation, diluting the profession, teaching students in accordance with their aptitude, and cultivating the students". That is, the first year of the university is based on the subject group, the second and third grades are trained according to the first-level discipline, and the fourth grade is under the guidance of the teacher, combined with the principle of voluntariness. Selecting the necessary professional courses or professional orientation courses will enable students to initially master the knowledge and skills necessary to participate in research projects (Brady, 2015; Klatt, Filip, \& Grzebyk, 2015).

Graduate training mode. With regard to postgraduate education, multi-modal and diversified training methods can be adopted under the current national system. The currently viable modes are "highway mode" and "overpass mode". Highway mode: including the "through train" of undergraduate, master's (Direct PhD), and MS-PhD student, we also call it the " $4+2+3$ " or " $4+2+4$ " mode and " $2+3$ ", or " $2+4$ " mode. 
Overpass mode: including the intersection within geological science, the intersection between geological science and adjacent disciplines, and the intersection of science and engineering disciplines (Wierik, Beishuizen, \& Os, 2015).

The advantage of the "high-speed road mode" is that it can solve the disconnection between bachelor, masters and doctoral, and at the same time, some outstanding students will continue to study. The "overpass mode" can not only solve the problem of fine division of the profession but also expand the students' horizons and expand the students' knowledge and innovation ability through the cross-cultivation of students from different disciplines, which is conducive to the cultivation of high-level mixed talents. Overall, the "high-speed road mode" has achieved good results after years of practice, and the promotion of the "overpass mode" has certain difficulties. The main obstacle is that the requirements for professional courses in the graduate entrance examination are too rigid. It is not conducive to students' cross-professional and interdisciplinary examinations.

\section{Reform of teaching content}

The reform of teaching content should not only meet the overall goal of talent cultivation, but also induce students' interest in earth science, so that students have the desire to acquire knowledge actively, and cultivate students' initiative and consciousness.

For undergraduates, the teaching content focuses on the basic and systematic nature of knowledge, embodying the way of thinking of the subject, and carefully selecting and optimizing the combination of teaching content in the case of total academic time compression. In order to cultivate students' practical ability and innovative ability, and appropriately increase the time of internship or experiment class, the content of the lecture and the experimental content are organically combined.

For graduate students, it emphasizes the frontier of teaching content, that is, on the basis of strengthening the basic theory, it increases the development of the discipline and the contents of major research results at home and abroad. At the same time, optimize the teaching content, delete the old parts, and simplify the secondary content. Moreover, teachers are required to teach students the unique ideas and methods of analyzing problems in the process of imparting knowledge, and to enhance the cultivation of students' innovative thinking and innovative ability.

Through the above research, we will build a multi-level talent training model for geological undergraduate majors with deep Industry-education integration. From the teaching team, curriculum teaching to the development of student engineering practice, the seamless integration of deep Industry-education integration is achieved.

\section{Conclusion}

Deepening Industry-education integration of geological talents is conducive to promoting the cultivation of geological talents and the interactive development of enterprises; It is conducive to solving the contradiction 
between the theoretical study of geological majors and the needs of enterprises; it is conducive to solving the professional courses between schools and enterprises. The problem of convergence is conducive to solving the problems between the production of enterprises and institutions and the contradiction between student training; it is conducive to alleviating the shortage of mathematics teaching, short internship time, and the internship base cannot meet the teaching needs.

Industry-education integration will become an important way to cultivate applied talents. The multi-level talent training mode of geological undergraduate majors with deep integration of production and education can effectively improve the employment of geological undergraduates. The comprehensive cooperation of education, production and research can benefit society, schools and enterprises.

\section{References}

Akomaning, E., Voogt, J. M., \& Pieters, J. M. (2011). Internship in vocational education and training: Stakeholders' perceptions of its organisation. Journal of Vocational Education and Training, 63(4), 575592. https://doi.org/10.1080/13636820.2011.590222

Alves, J., Carvalho, L., Carvalho, R., Correia, F., Cunha, J., Farinha, L., Fernandes, J., Ferreira, M., Lucas, E., Mourato, J., Nicolau, A., Nunes, S., Nunes, S., Oliveira, P., Pereira, C., Pinto, S., \& Silva, J. (2015). The impact of polytechnic institutes on the local economy. Tertiary Education and Management, 21(2), 81-98. https://doi.org/10.1080/13583883.2014.999110

Brady, N. (2015). 'Epistemicchaos': there context utilisation of under graduate curriculum design and pedagogic practice in a new university business school. British Journal of Sociology of Education, 36(8), 1236-1257.

Farias, M., \& Sevilla, M. P. (2015). Effectiveness of vocational high schools in students' access to and persistence in postsecondary vocational education. Research in Higher Education, 56(7), 693-718. https://doi.org/10.1007/s11162-015-9370-2

Klatt, M., Filip, P., \& Grzebyk, M. (2015). Understanding youth transition system in Pol and through the analysis of partner ships between vocational upper secondary school sand industry. Journal of Youth Studies, 18(9), 1186-1203. https://doi.org/10.1080/13676261.2015.1020938

Lepori, B., \& Kyvik, S. (2010). The research mission of universities of applied sciences and the future configuration of higher education systems in Europe. Higher Education Policy, 33(9), 295-316. https://doi.org/10.1057/hep.2010.11

Sanchez, J. (2013). The Impact of an Entrepreneurship Education Program on Entrepreneurial Competencies and Intention. Journal of Small Business Management, 51(3), 447- 465. https://doi.org/10.1111/jsbm.12025

Wierik, M., Beishuizen, J., \& Os, W. (2015). Career guidance and student success in Dutch higher vocational education. Studies in Higher Education, 40(10), 1947-1961. https://doi.org/10.1080/03075079.2014.914905 